\title{
Comparative study between ormeloxifene and oral contraceptive pills in the treatment of dysfunctional uterine bleeding
}

\author{
Jimitkumar Jamanadas Chhatrala*, Rutwa Chawada, H. B. Saini
}

\begin{abstract}
Department of Obstetrics \& Gynecology, SBKS Medical Institute and Research Centre, Pipariya, Wagodia, Vadodara, Gujarat, India
\end{abstract}

Received: 19 January 2015

Accepted: 16 February 2015

\author{
*Correspondence: \\ Dr. Jimitkumar Jamanadas Chhatrala, \\ E-mail: jimitchhatrala@gmail.com
}

Copyright: $\odot$ the author(s), publisher and licensee Medip Academy. This is an open-access article distributed under the terms of the Creative Commons Attribution Non-Commercial License, which permits unrestricted non-commercial use, distribution, and reproduction in any medium, provided the original work is properly cited.

\begin{abstract}
Background: Dysfunctional uterine bleeding is the most common cause of abnormal uterine bleeding. It can cause anemia, reduces the quality of life and increases healthcare costs. The present study was carried out to study the efficacy of ormeloxifene and compare it to combined oral contraceptive pills in the treatment of dysfunctional uterine bleeding.

Methods: 140 patients with dysfunctional uterine bleeding were selected randomly and divided into 2 groups of 70 each. Group A was given ormeloxifene tablet $60 \mathrm{mg}$ twice a week for 12 weeks followed by $60 \mathrm{mg}$ once a week for next 12 weeks. Group B was given low dose oral contraceptive pills containing $30 \mu \mathrm{g}$ of ethinyl estradiol and $150 \mu \mathrm{g}$ levonorgestrel from day 1 of the menstrual cycle to day 21 for 6 consecutive cycles. Follow up for six months on every cycle was done to assess the symptoms in the form of amount of bleeding (which was assessed by pictorial blood loss assessment chart score), recurrence of symptoms and also the side effects of each drug. Patient's improvement was assessed by performing blood hemoglobin level. Patient's level of satisfaction was judged by general health, limitation of social activity, sexual life and patient's wish to continue treatment with the same drug.

Results: The reduction in mean pictorial blood loss assessment score with ormeloxifene (174 to 75) was significantly more than with oral contraceptive pills $(171$ to 106$)$ at 6 months $(\mathrm{P}<0.05)$. In both the groups hemoglobin level increased but it was slightly more seen in patients treated with ormeloxifene as compared to oral contraceptive pills ( $7.0 \mathrm{gm} \%$ to $10.1 \mathrm{gm} \%$ vs. $7.2 \mathrm{gm} \%$ to $9.5 \mathrm{gm} \%, \mathrm{P}>0.05$ ). Recurrence of symptoms was $11 \%$ with ormeloxifene and $24 \%$ with oral contraceptive pills. The side effects were minimal in both the groups. $68.6 \%$ patients with ormeloxifene and $47.2 \%$ with oral contraceptive pills were highly satisfied with their treatment.

Conclusions: Ormeloxifene is more effective, with convenient dose schedule, well tolerated, with better compliance and shows less recurrence rate in treatment of dysfunctional uterine bleeding than oral contraceptive pills.
\end{abstract}

Keywords: Dysfunctional uterine bleeding, Oral contraceptive pills, Ormeloxifene, Selective estrogen receptor modulator

\section{INTRODUCTION}

Dysfunctional Uterine Bleeding (DUB) is abnormal uterine bleeding in the absence of any systemic, organic or iatrogenic cause. ${ }^{1}$ It is the most common cause of abnormal uterine bleeding which can affect any woman from menarche to menopause, occurring more commonly at the extremes of age. It can cause anemia, reduces the quality of life and increases healthcare costs because it is a major indication for referral to gynecological outpatient clinics. ${ }^{2}$ There have been so many hysterectomies carried out in past few years for menstrual disturbances, especially for dysfunctional uterine bleeding. 
Hysterectomy is a major surgical procedure that has risks, affects a woman's hormonal balance and overall health for the rest of her life. In recent years, concern has been expressed about possible long term complications of hysterectomy. Thus, more and more women are looking forward to an effective medical therapy. ${ }^{3-5}$

Progesterones, combined estrogen and progesterone, antifibrinolytics, non-steroidal anti-inflammatory drugs, danazol, gonadotropin releasing hormone analogues and levonorgesterol-releasing intrauterine devices have all been used with different results. Oral contraceptive pills, are commonly used for this purpose but being a hormonal drug, it is contraindicated in hypertension, current or past history of venous thromboembolism (VTE), ischemic heart disease, history of cerebrovascular accident, complicated valvular heart disease, migraine headache with focal neurological signs, breast cancer, diabetes with retinopathy/nephropathy/neuropathy, severe cirrhosis.

Ormeloxifene is a third generation Selective Estrogen Receptor Modulator (SERM), which acts selectively on estrogen receptors as agonist and antagonist in different tissues of the body. ${ }^{6}$ It has anti-estrogenic action on endometrium and breast and estrogenic action on bones, vagina, liver, cardiovascular and central nervous system. The ideal therapy in perimenopausal women is one that has no stimulation of endometrium, prevents bone loss, has no risk of breast cancer, has positive effect on lipids and cardiovascular system. Ormeloxifene satisfy these requirements. ${ }^{7,8}$

The present study was carried out to study the efficacy of ormeloxifene and compare it to combined oral contraceptive pills in the treatment of dysfunctional uterine bleeding.

\section{METHODS}

This is a prospective comparative study conducted in the department of obstetrics and gynecology, at Dhiraj general hospital, a tertiary care centre situated in the rural area of Vadodara, in which 140 women presenting with dysfunctional uterine bleeding were selected. Ethical approval was taken from the institutional ethical committee. Informed consent was taken from the patients. A detailed history and examination was done. As dysfunctional uterine bleeding is a diagnosis of exclusion, investigations were done to rule out any other possible cause for abnormal uterine bleeding. These were complete blood count including hemoglobin level, pregnancy test, thyroid stimulating hormone, coagulation profile, pap smear, pelvic ultrasound (to measure endometrial thickness, rule out any pelvic pathology and uterine anomaly).

140 patients with dysfunctional uterine bleeding were selected randomly and divided into 2 groups of 70 each. Group A was given ormeloxifene tablet $60 \mathrm{mg}$ twice a week for 12 weeks followed by $60 \mathrm{mg}$ once a week for next 12 weeks. Group B was given low dose oral contraceptive pills containing $30 \mu \mathrm{g}$ of ethinyl estradiol and $150 \mu \mathrm{g}$ levonorgestrel from day 1 of the menstrual cycle to day 21 for 6 consecutive cycles. The patients were asked to maintain a menstrual diary recording the days of bleeding, number of sanitary pads used, degree of soiling of each pad, number and size of clots passed, episodes of bleeding, the presence of menstrual cramps and other symptoms experienced. The patients were asked to use certain sanitary pads which have similar absorbent capacities.

In this study, objective assessment of menstrual blood loss was done by Pictorial Blood loss Assessment Chart (PBAC) as devised by Higham et al. PBAC is a simple and less time consuming procedure for objective assessment of menstrual blood loss. A PBAC score $\geq 100$ indicates a menstrual blood loss $\geq 80 \mathrm{ml}$ and is considered diagnostic for menorrhagia. ${ }^{9}$

Table 1: PBAC scoring system. ${ }^{9}$

\begin{tabular}{|lll|}
\hline \multirow{3}{*}{ PBAC } & scoring system \\
\cline { 2 - 3 } & Mildly soiled & 1 \\
\cline { 2 - 3 } & Moderately soiled & 5 \\
\cline { 2 - 3 } & Saturated & 20 \\
\hline \multirow{2}{*}{ Clots } & Small & 1 \\
\cline { 2 - 3 } & Large & 5 \\
\hline
\end{tabular}

Follow up for six months on every cycle was done to assess the symptoms in the form of amount of bleeding (which was assessed by PBAC score), recurrence of symptoms and also the side effects of each drug. Patient's improvement was assessed by performing blood hemoglobin level after completion of therapy. Patient's level of satisfaction was judged by general health, limitation of social activity, sexual life and patient's wish to continue treatment with the same drug.

\section{RESULTS}

Group A and Group B were both comparable with regards to mean age, parity, socioeconomic status and duration of symptoms. The pretreatment mean PBAC score and mean hemoglobin level were also comparable in both the groups.

Table 2: Clinical profile of both groups.

\begin{tabular}{|lll|}
\hline Clinical profile & $\begin{array}{l}\text { Group A } \\
(\text { ormeloxifene) } \\
(\mathrm{n}=70)\end{array}$ & $\begin{array}{l}\text { Group B (oral } \\
\text { contraceptive } \\
\text { pill) }(\mathrm{n}=70)\end{array}$ \\
\hline Age & 36.7 & 37.1 \\
\hline Parity & 2 & 2 \\
\hline Socioeconomical status & Lower & Lower \\
\hline $\begin{array}{l}\text { Duration of symptoms } \\
\text { (in months) }\end{array}$ & 8.3 & 8.5 \\
\hline Pretreatment PBAC score & 174 & 171 \\
\hline Hemoglobin $(\%)$ & 7.0 & 7.2 \\
\hline
\end{tabular}


Table 3: Comparison of PBAC score between ormeloxifene group and oral contraceptive pills group.

\begin{tabular}{|lll|} 
Mean PBAC score & $\begin{array}{l}\text { Group A } \\
(\text { ormeloxifene) } \\
(\mathbf{n}=70)\end{array}$ & $\begin{array}{l}\text { Group B (oral } \\
\text { contraceptive } \\
\text { pills) }(\mathbf{n}=70)\end{array}$ \\
\hline Before treatment & 174 & 171 \\
\hline After treatment & 75 & 106 \\
\hline
\end{tabular}

$\mathrm{P}<0.05$; Chi square=3.86; statistically significant

Table 3 shows the comparison of results with ormeloxifene and oral contraceptive pills by comparing mean PBAC score before treatment and 6 months after treatment.

In group A, mean PBAC score before treatment was 174, which was decreased significantly to 75 after 6 months of treatment with ormeloxifene. The mean pretreatment PBAC score in group B was 171 which reduced to 106 after 6 months of therapy with oral contraceptive pills. Comparing both the groups, reduction in PBAC score was noted more with patients treated with ormeloxifene as compared to oral contraceptive pills $(56.8 \% \mathrm{v} / \mathrm{s} 38 \%)$.

Table 4: Comparison of mean hemoglobin level between ormeloxifene and oral contraceptive pills group.

\begin{tabular}{|lll|}
$\begin{array}{l}\text { Mean hemoglobin } \\
(\text { gm \% })\end{array}$ & $\begin{array}{l}\text { Group A } \\
(\text { ormeoxifene) } \\
(\mathrm{n}=70)\end{array}$ & $\begin{array}{l}\text { Group B (oral } \\
\text { contraceptive } \\
\text { pills) }(\mathrm{n}=70)\end{array}$ \\
\hline Before treatment & 7.0 & 7.2 \\
\hline After treatment & 10.1 & 9.5 \\
\hline
\end{tabular}

$\mathrm{P}>0.05$; Chi square $=0.16$; statistically not significant

Table 4 shows the comparison of mean hemoglobin level between patients treated with ormeloxifene and oral contraceptive pills by comparing mean hemoglobin levels before treatment and 6 months after treatment.

In group A, mean hemoglobin level before treatment was $7.0 \mathrm{gm} \%$, which was increased significantly to 10.1 after 6 months of treatment. The mean pretreatment hemoglobin level in group B was $7.2 \mathrm{gm} \%$ which was increased to $9.5 \mathrm{gm} \%$ after 6 months of therapy. In both the groups hemoglobin level increased but it was slightly more seen patients treated with ormeloxifene as compared to oral contraceptive pills.

Table 5 shows the comparison of recurrence of symptoms after completion of 6 months treatment. In $8(11.4 \%)$ patients treated with ormeloxifene and 17 (24.3\%) patients treated with oral contraceptive pills had recurrence of symptoms. In our study, comparing both the groups recurrence of symptoms was more seen with oral contraceptive pills.
Table 5: Comparison of recurrence of symptoms after completion of treatment.

\begin{tabular}{|c|c|c|c|c|}
\hline \multirow{2}{*}{$\begin{array}{l}\text { Recurrence of } \\
\text { symptoms after } \\
\text { completion of } \\
\text { treatment }\end{array}$} & \multicolumn{2}{|c|}{$\begin{array}{l}\text { Group A } \\
\text { (ormeloxifene) } \\
(n=70)\end{array}$} & \multicolumn{2}{|c|}{$\begin{array}{l}\text { Group B (oral } \\
\text { contraceptive } \\
\text { pills) }(n=70)\end{array}$} \\
\hline & $\begin{array}{l}\text { No. of } \\
\text { patients }\end{array}$ & $\%$ & $\begin{array}{l}\text { No. of } \\
\text { patients }\end{array}$ & $\%$ \\
\hline $\begin{array}{l}\text { Recurrence } \\
\text { absent }\end{array}$ & 62 & $88.6 \%$ & 53 & $75.7 \%$ \\
\hline $\begin{array}{l}\text { Recurrence } \\
\text { present }\end{array}$ & 8 & $11.4 \%$ & 17 & $24.3 \%$ \\
\hline
\end{tabular}

$\mathrm{P}<0.05$; Chi square=3.94; statistically significant

Table 6: Adverse effects in both groups.

\begin{tabular}{|lll|}
\hline Adverse effects & $\begin{array}{l}\text { Group A } \\
(\text { ormeloxifene) } \\
(\mathrm{n}=70)\end{array}$ & $\begin{array}{l}\text { Group B (oral } \\
\text { contraceptive } \\
\text { pills) }(\mathrm{n}=70)\end{array}$ \\
\hline Nausea and vomiting & 0 & 5 \\
\hline Weight & 0 & 3 \\
\hline Headache & 1 & 4 \\
\hline Oligomenorrhea & 4 & 0 \\
\hline menopause & 3 & 0 \\
\hline
\end{tabular}

$\mathrm{P}<0.05$; Chi square $=16.67 ; \mathrm{df}=4$; statistically significant

In the ormeloxifene group, three patients attained menopause after completion of six months treatment, four patients had oligomenorrhoea and rest of the patients had regular normal cycles. Where as in oral contraceptive pills group, five patients had nausea and vomiting, three had complains of weight gain and four had mild headache during the course of treatment.

Table 7: Level of satisfaction with treatment in both the groups.

\begin{tabular}{|c|c|c|c|c|}
\hline \multirow{2}{*}{$\begin{array}{l}\text { Level of } \\
\text { satisfaction }\end{array}$} & \multicolumn{2}{|c|}{$\begin{array}{l}\text { Group A } \\
\text { (ormeloxifene) } \\
(\mathrm{n}=70)\end{array}$} & \multicolumn{2}{|c|}{$\begin{array}{l}\text { Group B (oral } \\
\text { contraceptive } \\
\text { pills) }(n=70)\end{array}$} \\
\hline & $\begin{array}{l}\text { No. of } \\
\text { patients }\end{array}$ & $\%$ & $\begin{array}{l}\text { No. of } \\
\text { patients }\end{array}$ & $\%$ \\
\hline Highly satisfied & 48 & $68.6 \%$ & 33 & $47.2 \%$ \\
\hline Satisfied & 16 & $22.8 \%$ & 25 & $35.7 \%$ \\
\hline Poorly satisfied & 6 & $8.6 \%$ & 12 & $17.1 \%$ \\
\hline
\end{tabular}

$\mathrm{P}<0.05$; Chi square $=6.75$; statistically significant

Patient's satisfaction is highly subjective and dependent upon the relative decrease in flow, duration, amount of menstrual bleeding and personal perception of wellbeing. Adverse effects of the drug and recurrence of symptoms also have significant impact on patient's own assessment. In this study, $8.6 \%$ of patients in ormeloxifene group and $17.1 \%$ of patients in oral contraceptive pills group were poorly satisfied with treatment. 


\section{DISCUSSION}

There are varieties of treatment available for dysfunctional uterine bleeding, from medical therapy to minimally invasive surgery to conventional hysterectomy. However, medical treatment should be the preferred modality of treatment when possible.

In study by Khare ${ }^{10}$ et al., decrease in mean PBAC score was $41.7 \%$ with ormeloxifene and $18 \%$ with oral contraceptive pills. Madal ${ }^{11}$ et al., also shows decrease in PBAC score $57 \%$ with ormeloxifene and $49 \%$ with oral contraceptive pills after three months of treatment. In our study in group A we have noted $56.8 \%$ and in group B $38 \%$ decrease in PBAC score which shows that ormeloxifene is a better drug in reducing the amount of menstrual bleeding.

In our study, in group A, mean hemoglobin level after treatment was improved from $7.0 \mathrm{gm} \%$, to 10.1 , whereas in group B from $7.2 \mathrm{gm} \%$ to $9.5 \mathrm{gm} \%$. In both the groups hemoglobin level increased but it was slightly more seen patients treated with ormeloxifene as compared to oral contraceptive pills.

In study by Khare ${ }^{10}$ et al., after six months of treatment there was less than $5 \%$ recurrence of symptoms noted in patients treated with ormeloxifene, whereas $30 \%$ with oral contraceptive pills. In our study recurrence was $11 \%$ with ormeloxifene and $24 \%$ with oral contraceptive pills which also favors for use of ormeloxifene.

The side effects were minimal in both the groups. Nausea, headache and weight gain was seen in few patients of oral contraceptive pills and oligomenorrhoea and menopause was present in the ormeloxifene group of patients. Khare ${ }^{10}$ et al. and Madal ${ }^{11}$ et al. also show the similar results.

The patient's satisfaction is always important with any treatment. In study by $\mathrm{Madal}^{11}$ et al, $58 \%$ patients with ormeloxifene and $52 \%$ with oral contraceptive pills where highly satisfied. In our study $68.6 \%$ patients with ormeloxifene and $47.2 \%$ with oral contraceptive pills were highly satisfied with their treatment, which also shows superiority of ormeloxifene over oral contraceptive pills in treatment of dysfunctional uterine bleeding.

\section{CONCLUSION}

Ormeloxifene is more effective, with convenient dose schedule, well tolerated, with better compliance and shows less recurrence rate in treatment of dysfunctional uterine bleeding than oral contraceptive pills.
Funding: No funding sources

Conflict of interest: None declared

Ethical approval: The study was approved by the institutional ethics committee

\section{REFERENCES}

1. Dutta DC. Abnormal menstrual bleeding. In: Hiralal Konar, eds. Textbook of Gynecology: 6th ed. New Delhi, India: Jaypee Brothers Medical Publishers; 2014: 180.

2. Frick KD, Clark MA, Steinwachs DM, Langenberg P, Stovall D, Munro MG, et al. Financial and qualityof-life burden of dysfunctional uterine bleeding among women agreeing to obtain surgical treatment. Womens Health Issues. 2009; 19:70-8.

3. Coulter A, Kelland J, Peto V, Rees MCP. Treating menorrhagia in primary care. An overview of drug trials and a survey of prescribing practice. Int J Tech Assess Health Care. 1995;11:456-71.

4. Winsor SHM, Fisher S, Hahn PM, Reid RL. Retrospective evaluation of the long term outcomes following conservative management of menorrhagia in ovulatory women. J Soc Obstet Gynecol Can. 1999;2:155-63.

5. Bhattacharyya TK, Banerji A. Efficacy of a selective estrogen receptor modulator: 'ormeloxifene' in management of dysfunctional uterine bleeding. South Asian Federat Obstet Gynaecol. 2010;2:207-11.

6. Shelly W, Draper MW, Krishnan V, Wong M, Jaffe RB. Selective estrogen receptor modulators: an update on recent clinical findings. Obstet Gynecol Surv. 2008;63:163-81.

7. Singh MM. Centchroman, a selective estrogen receptor modulator, as a contraceptive and for the management of hormone-related clinical disorders. Med Res Rev. 2001;21:302-7.

8. Osborne CK, Zhao H, Fuqua SA. Selective estrogen receptor modulators: structure, function, and clinical use. J Clin Oncol. 2000;18:3172-86.

9. Higham JM, O'Brien PMS, Shaw RW. Assessment of menstrual blood loss using a pictorial chart. Br J Obstet Gynaecol. 1990;97:734-9.

10. Khare VE, Ghosh GO, Patil PO, Nagar NI. Ormeloxifene $\mathrm{HCl}$ vs. combined oral contraceptive pill in treatment of dub. JEMDS. 2014;4:1026-33.

11. Mandal DE, Parmanik SU, Surana SI, Hazra AB, Mandal SA, Maity TA. Comparative study of lowdose oral contraceptive pill and ormeloxifene in the treatment of dysfunctional uterine bleeding. Int $\mathbf{J}$ Health Allied Sci. 2014;4:225-31.

DOI: $10.5455 / 2320-1770 . i j \operatorname{rog} 20150415$

Cite this article as: Chhatrala JJ, Chawada R, Saini HB. Comparative study between ormeloxifene and oral contraceptive pills in the treatment of dysfunctional uterine bleeding. Int J Reprod Contracept Obstet Gynecol 2015;4:366-9. 